\title{
Natural occurrence of aflatoxins and ochratoxin A in meju and soybean paste produced in South Korea
}

\author{
Seong Eun Jeong, Soo Hyun Chung and Sung-Yong Hong * (i)
}

\begin{abstract}
In this study, we investigated the occurrence of aflatoxins (AFs) and ochratoxin A (OTA) in meju and soybean paste produced in South Korea. Samples were collected from three regions divided on the basis of climate in South Korea. A total of 100 meju samples were analyzed over 3 years (2012-2015), and 45 soybean paste samples were analyzed in 2016. Mycotoxins were extracted with an immunoaffinity column method and quantified by high-performance liquid chromatography. AFs were detected in 10 of meju (10\%) and 11 of soybean paste samples (24.4\%) with concentrations of $0.2-48.3 \mu \mathrm{g} / \mathrm{kg}$ and $0.88-16.17 \mu \mathrm{g} / \mathrm{kg}$, respectively. OTA was detected in 50 of meju (50\%) and 22 of soybean paste samples (48.9\%) with concentrations of $0.1-193.2 \mu \mathrm{g} / \mathrm{kg}$ and $0.88-26.29 \mu \mathrm{g} / \mathrm{kg}$, respectively. Mycotoxin contamination in meju was more common in the central region than in the southern areas. Thus, more mycotoxins were produced in the central region owing to less fungal competition in meju during fermentation inside households. We also found that about $91 \%$ of AFs and $73 \%$ of OTA in meju were degraded after the production of soybean paste and soy sauce. Even after degradation of AFs and OTA, the levels of AFB 1 and OTA were $0.5 \mu \mathrm{g} / \mathrm{kg}$ and $7.5 \mu \mathrm{g} / \mathrm{kg}$ in soy sauce and $11.9 \mu \mathrm{g} / \mathrm{kg}$ and $190.4 \mu \mathrm{g} / \mathrm{kg}$ in soybean paste, respectively. Thus, our results suggest the need for constant monitoring of meju and soybean paste for AFs and OTA.
\end{abstract}

Keywords: Aflatoxin, HPLC, Meju, Ochratoxin A, Soybean

\section{Introduction}

Soybeans and its products are among the major protein sources in East Asia. Meju is a fermented soybean food used as a raw material for the preparation of traditional fermented foods such as soy sauce and soybean paste in South Korea [1, 2]. These products have been manufactured for centuries at home by traditional means, wherein the natural microflora, especially storage fungi, participates in the fermentation process. These molds produce the enzymes for conversion of proteins and carbohydrates into amino acids, sugars, organic acids, alcohol, and esters, thereby conferring the characteristic flavor of meju [3]. In South Korea, the manufacture of fermented foods such as meju using traditional methods, which are preferred over commercial products, is raising concerns,

*Correspondence: lunohong@korea.ac.kr

Department of Integrated Biomedical and Life Science, Korea University, Seoul 02841, Republic of Korea owing to the possibility of contamination with mycotoxins, especially aflatoxins (AFs) and ochratoxin A (OTA).

AFs are a group of toxic metabolites produced by Aspergillus species such as A. flavus, A. parasiticus, A. pseudotamarii, and $A$. nomius $[4,5]$. In general, $A$. flavus and $A$. pseudotamarii produce $\mathrm{AFB}_{1}$ and $\mathrm{AFB}_{2}$, while $A$. parasiticus and $A$. nomius produce $\mathrm{AFG}_{1}$ and $\mathrm{AFG}_{2}$. The carcinogenicity, mutagenicity, and teratogenicity of $\mathrm{AFB}_{1}$ and its metabolites have been well documented. Thus, AFs are classified as Group 1 carcinogens (carcinogenic to humans) by the International Agency for Research on Cancer (IARC) [6]. OTA is a toxic secondary metabolite produced by several Aspergillus species and Penicillium verrucosum, which are found in contaminated agricultural crops [7]. OTA poses a serious threat to public health and causes severe economic losses worldwide because it can be found in animal feed such as corn and stored grains as well as in food products such as flour, 
peas, peanuts, spices, and coffee beans [8]. IARC has categorized OTA as a possible human carcinogen (Group 2B) [9]. Both groups of mycotoxins may contaminate various food commodities, including meju [1, 2, 10, 11]. Considering that meju is a main ingredient in soybean paste and soy sauce, which are used as seasoning agents and condiments in many Korean foods, the contamination of meju with AFs and OTA may affect most Korean foods. The Korean government has set the maximum limits of total AF at $15 \mu \mathrm{g} / \mathrm{kg}, \mathrm{AFB}_{1}$ at $10 \mu \mathrm{g} / \mathrm{kg}$, and OTA at $20 \mu \mathrm{g} / \mathrm{kg}$ in $m e j u$. Several analytical methods have been developed to quantify the two mycotoxins, such as enzyme-linked immunosorbent assay (ELISA) [12], thinlayer chromatography (TLC) [13], and high-performance liquid chromatography (HPLC) [14]. ELISA and TLC methods are less selective than other analytical methods and are prone to interference by sample matrices $[15,16]$. HPLC has been employed to determine AFs and OTA at low levels in food $[10,15]$. The analysis of AFs and OTA in meju is complicated because of the distribution of lipids and proteins in the soy-fermented materials that are co-extracted with AFs and OTA. Therefore, a specific purification method is desirable before HPLC analysis. Highly pure AFs and OTA can be obtained by passing meju through an immunoaffinity column (IAC), which uses specific antibody binding. Such an approach would provide an easy and straightforward solution to extract pure mycotoxins and consequently overcome the problems of interference from other compounds present in meju. In this regard, the present study aimed to investigate the contamination of AFs and OTA in meju and soybean paste samples collected in South Korea. We also observed the transfer rates of mycotoxins to soy sauce and soybean paste produced from the collected meju samples, which were severely contaminated with AFs and OTA.

\section{Materials and methods Sample collection}

Meju was randomly collected from traditional markets in South Korea between 2012 and 2015, while soybean paste was obtained in 2016 under the previously described conditions. The sampling areas were chosen by dividing the nation into three climatic zones based on the temperature and precipitation characteristics observed at 60 points by the Korea Meteorological Administration for 25 years [17]. The first region included the Yeongdong region in Gangwon and Gyeonggi provinces (average temperature, $11.7{ }^{\circ} \mathrm{C} /$ year; average precipitation, $1286.6 \mathrm{~mm} /$ year), while the second region included Chungcheong, Gyeongsangbuk, and Jeollabuk provinces (average temperature, $11.3^{\circ} \mathrm{C} /$ year; average precipitation, $1263.4 \mathrm{~mm} /$ year). The third region included southern
Yeongho-Nam and the coastal areas of Jeollanam and Gyeongsangnam provinces (average temperature, $13{ }^{\circ} \mathrm{C} /$ year; average precipitation, $1346.9 \mathrm{~mm} /$ year). About 16-18 samples were collected each year. All samples were stored in a freezer $\left(-20^{\circ} \mathrm{C}\right)$ until analysis.

\section{Standards and reagents}

AF and OTA analytical standards were purchased from Sigma-Aldrich (St. Louis, MO, USA) and stored at $-18{ }^{\circ} \mathrm{C}$ until use. Stock solutions of AF were stored in a mixture of benzene and acetonitrile $(\mathrm{ACN})(98: 2, \mathrm{v} / \mathrm{v})$ and working standard solutions were prepared by diluting the stock standard solution to $10 \mu \mathrm{g} / \mathrm{mL}$ in $10 \% \mathrm{ACN}$. OTA was stored in a mixture of toluene and acetic acid (99:1, v/v). Working standard solutions were prepared by diluting stock standard solutions to $10 \mu \mathrm{g} / \mathrm{mL}$ in a mixture of $\mathrm{ACN}$, methanol $(\mathrm{MeOH})$, and acetic acid (HAC) $(99: 99: 2, v / v)$. All solvents used for the preparation of the mobile phase were of HPLC grade and obtained from J.T. Baker (Center Valley, PA, USA). Trifluoroacetic acid (TFA) was obtained from Sigma-Aldrich. All solvents were filtered through $0.45 \mu \mathrm{m}$ membrane filters (Whatman plc, Maidstone, UK). Pure water was obtained from a Milli-Q apparatus (Millipore, Billerica, MA, USA). IACs were supplied by VICAM (Milford, MA, USA).

\section{Extraction procedure and IAC clean-up}

The levels of AFs in meju were detected according to the previously published procedures with some minor modifications [18-20]. Briefly, $20 \mathrm{~g}$ of each sample was mixed in a $250 \mathrm{~mL}$ Erlenmeyer flask containing $100 \mathrm{~mL}$ of ACN and water $(60: 40, \mathrm{v} / \mathrm{v})$, and the mixture was mechanically shaken by a wrist action shaker (EYELA, Tokyo, Japan) for $1 \mathrm{~h}$. The extract was filtered through Whatman filter paper No. 4, and $10 \mathrm{~mL}$ of the filtrate was diluted with $40 \mathrm{~mL}$ of phosphate buffered saline (PBS, pH 7.4). After $50 \mathrm{~mL}$ of mixture was passed through a glass microfiber filter (Whatman GF/A, UK), $10 \mathrm{~mL}$ of the filtrate was passed through an IAC (Aflatest ${ }^{\circledR}$, VICAM, USA). The IAC was washed with $10 \mathrm{~mL}$ distilled water. AFs were then eluted with $2 \mathrm{~mL} \mathrm{MeOH}$ at a flow of $1-1.5 \mathrm{~mL} / \mathrm{min}$. The methanol eluate was evaporated to dryness under a stream of nitrogen at $50{ }^{\circ} \mathrm{C}$, and $\mathrm{AFs}$ were reconstituted in $500 \mu \mathrm{L}$ of $10 \%$ ACN-TFA.

The levels of AFs in soybean paste were analyzed according to the previously published procedures with some minor modifications [21]. In brief, $25 \mathrm{~g}$ of each sample was extracted with $100 \mathrm{~mL}$ of $\mathrm{MeOH}$ :water (70:30, v/v) containing $1 \%$ sodium chloride $(\mathrm{NaCl})$ using a mechanical shaker for $20 \mathrm{~min}$. The extract was filtered through Whatman No. 1 filter paper, and $10 \mathrm{~mL}$ of the filtrate was diluted with $30 \mathrm{~mL}$ with deionized water. After vigorously mixed, the mixture was passed through an 
Aflatest ${ }^{\circledR} \mathrm{IAC}$ at a flow rate of about $3 \mathrm{~mL} / \mathrm{min}$ ( 1 drop/s). The IAC was washed with distilled water $(10 \mathrm{~mL})$ at the same flow rate until $2-3 \mathrm{~mL}$ of air passed through it to remove water. AFs were finally eluted from the column with $3 \mathrm{~mL} \mathrm{ACN}$ at the same flow rate and it was flushed with air. The eluate was evaporated under a gentle stream of $\mathrm{N}_{2}$ at $50{ }^{\circ} \mathrm{C}$. The dry residues were re-dissolved and derivatized in $200 \mu \mathrm{L}$ TFA, allowing them to stand for $15 \mathrm{~min}$. The sample was then diluted with 800 $\mu \mathrm{L}$ of ACN:water $(20: 80, \mathrm{v} / \mathrm{v})$, filtered through a $0.45 \mu \mathrm{m}$ syringe filter $(13 \mathrm{~mm} \times 0.2 \mu \mathrm{m}$, GHP; Pall Corporation, Ann Arbor, MI, USA), and transferred into HPLC vials for auto injection.

We analyzed the levels of OTA in meju according to the previously published methods with some minor modifications [20, 22, 23]. Each sample (25 g) was put in a $250 \mathrm{~mL}$ Erlenmeyer flask containing $100 \mathrm{~mL}$ of ACN:water $(60: 40, v / v)$, and the mixture was mechanically shaken with a wrist action shaker (EYELA, JAPAN) for $1 \mathrm{~h}$. The extract was filtered through Whatman No. 4 filter paper, and $5 \mathrm{~mL}$ of the filtrate was diluted in $55 \mathrm{~mL}$ PBS. After about $55 \mathrm{~mL}$ of mixture was passed through a glass microfiber filter (Whatman GF/A, UK), $10 \mathrm{~mL}$ of the filtrate was passed through an IAC (OchrTest IAC ${ }^{\circledR}$, VICAM, USA). The IAC was washed with $10 \mathrm{~mL}$ distilled water and OTA was eluted with $2 \mathrm{~mL}$ methanol at a flow rate of $1-1.5 \mathrm{~mL} / \mathrm{min}$. The methanol eluate was evaporated to dryness under a stream of nitrogen at $50{ }^{\circ} \mathrm{C}$, and the OTA was reconstituted in $500 \mu \mathrm{L}$ of the mobile phase solution (ACN:MeOH:HAC, 99:99:2, v/v).

The OTA in soybean paste was analyzed according to the annual report of the Korean Food and Drug Admin-
Assessment of the linearity, precision and sensitivity of the analytical method for determination of levels of AFs and OTA

The linearity of a series of AFs concentrations in the analytical method was assessed by a standard curve using eight levels of AFs $(0.01 \mu \mathrm{g} / \mathrm{kg}, 0.05 \mu \mathrm{g} / \mathrm{kg}, 0.1 \mu \mathrm{g} /$ $\mathrm{kg}, 0.5 \mu \mathrm{g} / \mathrm{kg}, 1.0 \mu \mathrm{g} / \mathrm{kg}, 2.0 \mu \mathrm{g} / \mathrm{kg}, 5.0 \mu \mathrm{g} / \mathrm{kg}$, and $10 \mu \mathrm{g} /$ $\mathrm{kg})$ for $m e j u$ and AFs $(0.005 \mu \mathrm{g} / \mathrm{kg}, 0.01 \mu \mathrm{g} / \mathrm{kg}, 0.05 \mu \mathrm{g} /$ $\mathrm{kg}, 0.1 \mu \mathrm{g} / \mathrm{kg}, 0.5 \mu \mathrm{g} / \mathrm{kg}, 1.0 \mu \mathrm{g} / \mathrm{kg}, 5.0 \mu \mathrm{g} / \mathrm{kg}$, and $10 \mu \mathrm{g} /$ $\mathrm{kg}$ ) for soybean paste, which were dissolved in the mobile phase solution (ACN:MeOH:distilled water $=17: 17: 66$, $\mathrm{v} / \mathrm{v} / \mathrm{v})$. The linearity of a series of OTA concentrations in the analytical method for meju and soybean paste samples was assessed by a standard curve using eight levels of OTA $(0.005 \mu \mathrm{g} / \mathrm{kg}, 0.01 \mu \mathrm{g} / \mathrm{kg}, 0.05 \mu \mathrm{g} / \mathrm{kg}, 0.1 \mu \mathrm{g} / \mathrm{kg}$, $0.5 \mu \mathrm{g} / \mathrm{kg}, 1.0 \mu \mathrm{g} / \mathrm{kg}, 5.0 \mu \mathrm{g} / \mathrm{kg}$, and $10 \mu \mathrm{g} / \mathrm{kg}$ ) dissolved in the mobile phase solution (ACN:water:HAC = 99:99:2, $\mathrm{v} / \mathrm{v} / \mathrm{v})$. Each standard solution for AFs or OTA was injected into HPLC-FLD in triplicate. The calibration curve was constructed by plotting the peak areas (y axis) versus AF or OTA concentrations (x axis) in the HPLC analysis. The linearity was determined by linear regression analysis and expressed as coefficient of determination $\left(\mathrm{r}^{2}\right)$.

The precision of the analytical method was evaluated by the recovery experiments. The recovery experiments were performed with AF- and OTA-free meju and soybean paste samples, which were spiked with either AFs at $1.0 \mu \mathrm{g} / \mathrm{kg}$ and $10.0 \mu \mathrm{g} / \mathrm{kg}$ or OTA at $2.0 \mu \mathrm{g} / \mathrm{kg}$ and $10.0 \mu \mathrm{g} / \mathrm{kg}$. The experiment was carried out in triplicate, including a double blank. Recovery was calculated by the following equation.

$$
\text { Recovery }=\frac{\text { AF or OTA concentration measured from the spiked sample }}{\text { AF or OTA concentration used for spiking the sample }} \times 100
$$

istration (KFDA) [24]. Briefly, $25 \mathrm{~g}$ of each sample was extracted with $100 \mathrm{~mL} \mathrm{MeOH}$ :water (70:30, v/v) using a mechanical shaker for $3 \mathrm{~min}$. The extract was filtered with Whatman No. 1 filter paper, and $4 \mathrm{~mL}$ of the filtrate was diluted in $40 \mathrm{~mL}$ PBS and subjected to vigorous agitation. After the mixture $(44 \mathrm{~mL})$ was passed through an OchrTest $\mathrm{IAC}^{\circledR}$ at a flow rate of about $3 \mathrm{~mL} / \mathrm{min}(2$ $\mathrm{drop} / \mathrm{s})$, the column was washed with distilled water $(10 \mathrm{~mL})$ at the same flow rate until $2-3 \mathrm{~mL}$ of air passed through it to ensure the removal of water. The OTA was eluted with $2 \mathrm{~mL} \mathrm{MeOH}$ at a flow of $1-1.5 \mathrm{~mL} / \mathrm{min}$. The $\mathrm{MeOH}$ eluate was evaporated to dryness under a stream of nitrogen at $50{ }^{\circ} \mathrm{C}$, and the OTA was reconstituted in $500 \mu \mathrm{L}$ of the mobile phase solution (ACN:MeOH:HAC, 99:99:2, v/v).
The sensitivity of the methods was determined by limit of detection (LOD) and limit of quantification (LOQ) for meju and soybean paste samples. These were calculated as a signal-to-noise $(\mathrm{S} / \mathrm{N})$ ratio of $3: 1$ and $10: 1$, respectively, which were determined by using HPLC software (Analyst 1.6 software program).

\section{HPLC analysis}

A Dionex Ultimate 3000 UHPLC system (Thermo Scientific, Waltham, MA, USA) was used to detect AF and OTA. Separation was carried out using a Nova-Pack C18 column (4.6 mm $\times 250 \mathrm{~mm}, 5 \mu \mathrm{m}$; Waters, Milford, MA, USA). The injection volume for the AF or OTA standards and samples was $50 \mu \mathrm{L}$. For AF analysis, the mobile phase (ACN:MeOH:distilled water $=17: 17: 66, \mathrm{v} / \mathrm{v} / \mathrm{v})$ was 


\begin{tabular}{lcll}
$\begin{array}{l}\text { Table } 1 \\
\text { in } \boldsymbol{m e j u} \text { Recovery of }\end{array}$ & $\mathbf{A F B}_{\mathbf{1}}, \mathbf{A F B}_{\mathbf{2}}, \mathbf{A F G}_{\mathbf{1}}, \mathbf{A F G}_{\mathbf{2}}$, and OTA \\
\hline Mycotoxin & $\begin{array}{l}\text { Spiked } \\
\text { concentration } \\
(\boldsymbol{\mu} \mathbf{g} / \mathbf{k g})\end{array}$ & $\begin{array}{l}\text { Mean } \\
\text { recovery } \\
(\%)^{\mathbf{a}}\end{array}$ & $\begin{array}{l}\text { Relative standard } \\
\text { deviations (RSD) (\%) }\end{array}$ \\
\hline $\mathrm{AFB}_{1}$ & 1.0 & 99.8 & 6.49 \\
& 10.0 & 97.5 & 3.36 \\
$\mathrm{AFB}_{2}$ & 1.0 & 91.2 & 7.97 \\
& 10.0 & 90.5 & 7.31 \\
$\mathrm{AFG}_{1}$ & 1.0 & 92.2 & 6.98 \\
& 10.0 & 79.7 & 4.76 \\
$\mathrm{AFG}_{2}$ & 1.0 & 71.2 & 7.24 \\
& 10.0 & 95.1 & 2.13 \\
$\mathrm{OTA}_{2}$ & 2.0 & 75.6 & 4.26 \\
& 10.0 & 93.3 & 4.22
\end{tabular}

${ }^{a}$ Mean recovery indicate the average of triplicates at each level

pumped at a flow rate of $0.5 \mathrm{~mL} / \mathrm{min}$, giving a total run time of $20 \mathrm{~min}$. A fluorescence detector was used for the determination of AFs at an excitation wavelength of $360 \mathrm{~nm}$ and emission wavelength of $440 \mathrm{~nm}$. For OTA analysis, the mobile phase (ACN:water:HAC $=99: 99: 2$, $\mathrm{v} / \mathrm{v} / \mathrm{v}$ ) was pumped at a flow rate of $0.8 \mathrm{~mL} / \mathrm{min}$, giving a total run time of $20 \mathrm{~min}$. A fluorescence detector was used for the determination of OTA at an excitation wavelength of $330 \mathrm{~nm}$ and emission wavelength of $460 \mathrm{~nm}$.

\section{Statistical analysis}

Statistical analyses were performed by Student's $t$ test using SigmaStat scientific statistical software (version 1.0, Jandel corporation, San Rafael, CA, USA).

\section{Results and discussion}

Assessment of the linearity, precision, and sensitivity of the analytical method to determine levels of AFs and OTA

The precision of the method was evaluated from the recovery rate of AFs and OTA obtained from the samples spiked with known concentrations of AF and OTA standard solutions. The recovery rate was calculated using the equation described in the Materials and Methods. The recovery rates of AFs and OTA in meju samples are shown in Table 1, while the typical HPLC chromatograms of AFs and OTA are shown in Fig. 1. The recovery rates of AFs were in the range of $71.2-99.8 \%$ at $1 \mu \mathrm{g} / \mathrm{kg}$ and $10 \mu \mathrm{g} / \mathrm{kg}$ of levels spiked with AFs, and the recovery rates of OTA were in the range of $75.6-93.3 \%$ at $2 \mu \mathrm{g} /$ $\mathrm{kg}$ and $10 \mu \mathrm{g} / \mathrm{kg}$ of levels fortified with OTA. The recovery rates of AFs and OTA in soybean paste samples are shown in Table 2. The recovery rates of AFs were in the range of $82.8-97.6 \%$ at $1 \mu \mathrm{g} / \mathrm{kg}$ and $10 \mu \mathrm{g} / \mathrm{kg}$ of levels spiked with AFs, and the recovery rates of OTA were in the range of $90.5-92.8 \%$ at $2 \mu \mathrm{g} / \mathrm{kg}$ and $10 \mu \mathrm{g} / \mathrm{kg}$ of levels fortified with OTA.

The recovery rates of AFs and OTA in all the samples satisfied the permissible limits of the recovery recommended by the Codex or Association of Official Analytical Chemists (AOAC) [25]. The Codex recommends $60-120 \%$ of recovery rates in food samples contaminated with $1-10 \mu \mathrm{g} / \mathrm{kg}$ mycotoxins, and the guideline for the recoveries by AOAC is $70-125 \%$ in food samples contaminated with $10 \mu \mathrm{g} / \mathrm{kg}$ mycotoxins. In addition, the relative standard deviation (RSD) values of AFs and OTA (2.13$7.97 \%$ ) were below $15 \%$, which is in accordance with the recommendation for food samples contaminated with $10 \mu \mathrm{g} / \mathrm{kg}$ mycotoxins by AOAC. Thus, we concluded that the analytical method had good recoveries from meju.

The sensitivity of the method using HPLC was determined by LOD and LOQ. The LOD was $0.05 \mu \mathrm{g} / \mathrm{kg}$ for $\mathrm{AFB}_{1}$ and $\mathrm{AFB}_{2}, 0.2 \mu \mathrm{g} / \mathrm{kg}$ for $\mathrm{AFG}_{1}$ and $\mathrm{AFG}_{2}$, and $0.03 \mu \mathrm{g} / \mathrm{kg}$ for OTA in meju, whereas the LOD was $0.01 \mu \mathrm{g} / \mathrm{kg}$ for $\mathrm{AFB}_{1}$ and $\mathrm{AFB}_{2}, 0.05 \mu \mathrm{g} / \mathrm{kg}$ for $\mathrm{AFG}_{1}$ and $\mathrm{AFG}_{2}$, and $0.01 \mu \mathrm{g} / \mathrm{kg}$ for OTA in soybean paste samples (Tables 3 and 4). The LOQ was $0.15 \mu \mathrm{g} / \mathrm{kg}$ for $\mathrm{AFB}_{1}$ and $\mathrm{AFB}_{2}, 0.6 \mu \mathrm{g} / \mathrm{kg}$ for $\mathrm{AFG}_{1}$ and $\mathrm{AFG}_{2}$, and $0.1 \mu \mathrm{g} / \mathrm{kg}$ for OTA in meju, whereas the LOQ was $0.03 \mu \mathrm{g} / \mathrm{kg}$ for $\mathrm{AFB}_{1}$ and $\mathrm{AFB}_{2}, 0.15 \mu \mathrm{g} / \mathrm{kg}$ for $\mathrm{AFG}_{1}$ and $\mathrm{AFG}_{2}$, and $0.03 \mu \mathrm{g} / \mathrm{kg}$ for OTA in soybean paste samples. They were as low as those for the detection of trace amounts of AFs and OTA.

The linearity of a series of AF or OTA concentrations in the analytical method was assessed by each standard curve using 8 levels of standard solutions for each toxin. The linearity was determined by linear regression analysis. The curves for AFs or OTA were greater than 0.99 (Tables 3 and 4). Therefore, we concluded that the calibration curves were linear in the range of $0.01-10 \mu \mathrm{g} / \mathrm{kg}$ of AFs for meju, in the range of $0.005-10 \mu \mathrm{g} / \mathrm{kg}$ of AFs for soybean paste, and in the range of $0.005-10 \mu \mathrm{g} / \mathrm{kg}$ of OTA for meju and soybean paste.

\section{Monitoring the levels of AFs and OTA in meju samples}

The analytical method validated above was used for the determination of levels of AFs and OTA in 100 meju samples collected from local markets in South Korea. Ten out of 100 samples $(10 \%)$ were contaminated with total AFs at $0.2-41.3 \mu \mathrm{g} / \mathrm{kg}$. In addition, 9 samples (9\%) were contaminated with $\mathrm{AFB}_{1}$ at $0.6-21.4 \mu \mathrm{g} / \mathrm{kg}$ (Table 5). The mean concentration was $1.45 \mu \mathrm{g} / \mathrm{kg}$ and $0.86 \mu \mathrm{g} / \mathrm{kg}$ for $\mathrm{AFB}_{1}$ and total AFs, respectively. The levels of $\mathrm{AFB}_{1}$ and total $\mathrm{AF}$ in three meju samples analyzed (3\%) exceeded the regulatory limits for $\mathrm{AFB}_{1}(10 \mu \mathrm{g} / \mathrm{kg})$ and total AFs $(15 \mu \mathrm{g} / \mathrm{kg})$ set by the KFDA. In general, soybeans are believed to be a poor substrate for AF production [26]. Therefore, it is highly likely that AF production occurs during the fermentation process for making meju. Several 


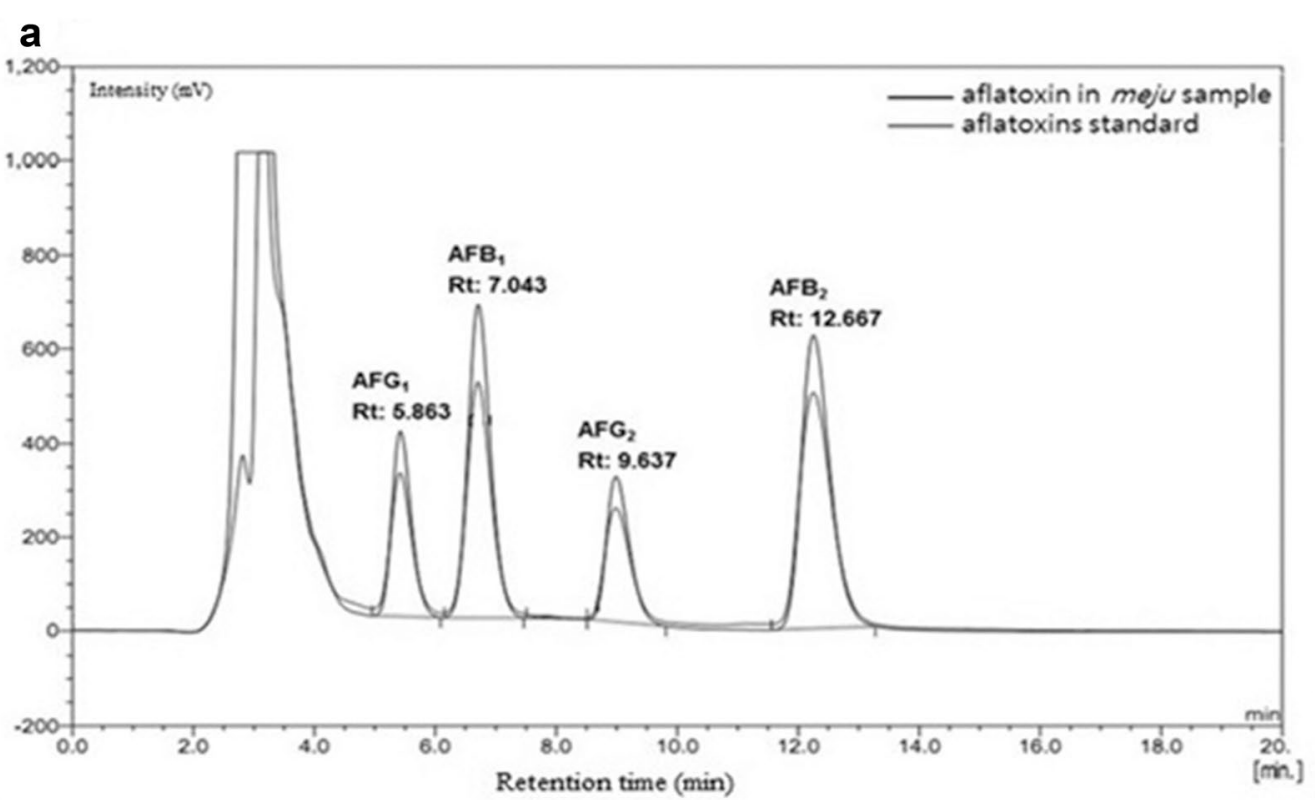

b

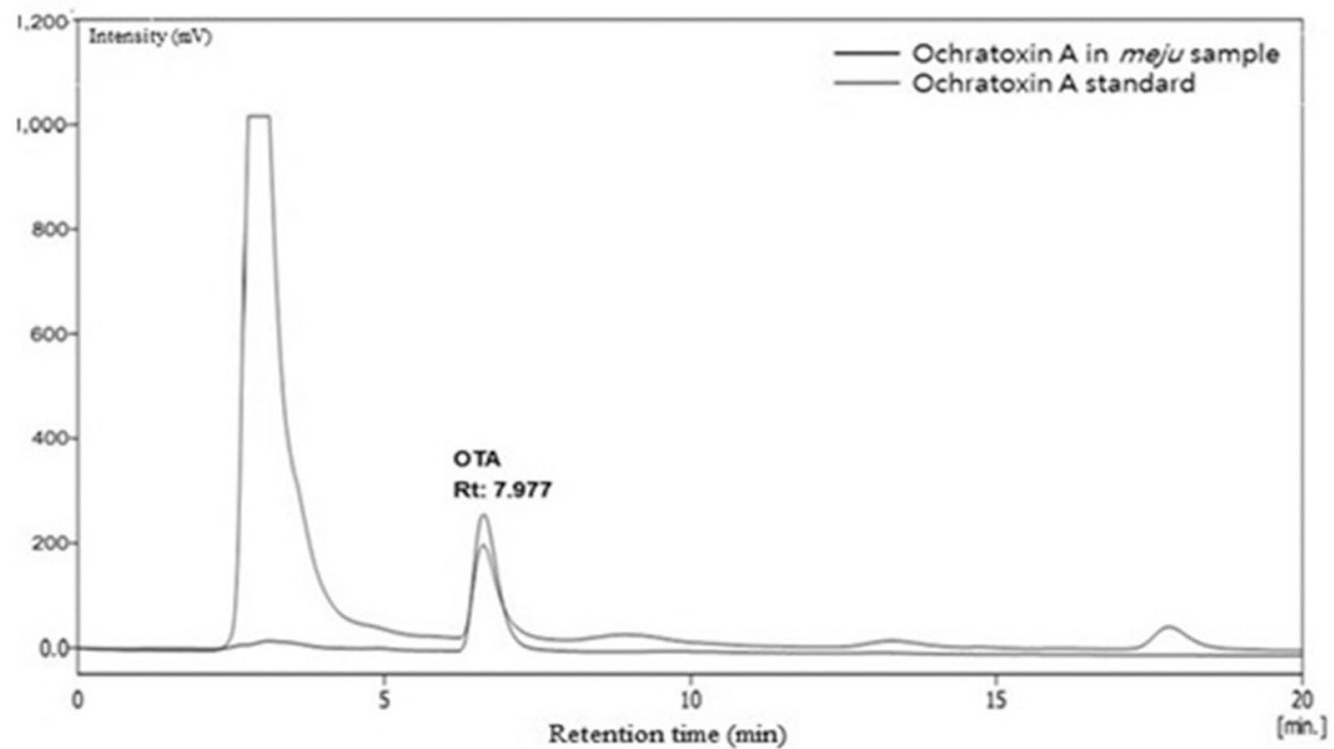

Fig. $1 \mathrm{HPLC}$ chromatograms of a standard solution containing $10 \mu \mathrm{g} / \mathrm{L}$ of AFs and a meju sample naturally contaminated with $9 \mu \mathrm{g} / \mathrm{kg}$ of AFs and $\mathbf{b}$ standard solution containing $10 \mu \mathrm{g} / \mathrm{L}$ of OTA and a meju sample naturally contaminated with $8.7 \mu \mathrm{g} / \mathrm{kg}$ of OTA

studies have reported on the levels of AFs in soybean and soybean products. One study showed AF contamination in $41.7 \%$ of meju samples, and the mean levels were lower $(6.9 \mu \mathrm{g} / \mathrm{kg})$ than the legal limits [18]. Despite the detection of contamination, the authors concluded that the presence of AFs in meju sold in South Korea was not a serious threat to human health. In addition, in Pakistan, Lutfullah and collaborators found $\mathrm{AFB}_{1}$ contamination in $15 \%$ of soybean samples, with an average concentration of $6.4 \mu \mathrm{g} / \mathrm{kg}$ [16]. The levels of AFs in a traditional Korean fermented soybean food was similar to those of AF in soybean products marketed in other countries.

Fifty samples of 100 meju samples (50\%) were contaminated with $0.1-193.2 \mu \mathrm{g} / \mathrm{kg}$ of OTA, which were analyzed with HPLC (Table 5). The average concentration of OTA was $10.24 \mu \mathrm{g} / \mathrm{kg}$. The levels of OTA in nine meju samples analyzed (9\%) exceeded the legal limits for OTA set by the KFDA $(20 \mu \mathrm{g} / \mathrm{kg})$. In particular, six meju samples exceeded the permissible limits by $5-10$ times. Information about levels of OTA in soybean fermented food such 
Table 2 Recovery of $A F B_{1}, \mathrm{AFB}_{2}, \mathrm{AFG}_{1}, \mathrm{AFG}_{2}$, and OTA in soybean paste

\begin{tabular}{lcll}
\hline Mycotoxin & $\begin{array}{l}\text { Spiked } \\
\text { concentration } \\
(\boldsymbol{\mu g} / \mathbf{k g})\end{array}$ & $\begin{array}{l}\text { Mean } \\
\text { recovery } \\
(\%)^{\mathbf{a}}\end{array}$ & $\begin{array}{l}\text { Relative standard } \\
\text { deviations (RSD) (\%) }\end{array}$ \\
\hline $\mathrm{AFB}_{1}$ & 1.0 & 97.6 & 1.65 \\
$\mathrm{AFB}_{2}$ & 10.0 & 94.1 & 3.33 \\
& 1.0 & 91.3 & 2.95 \\
$\mathrm{AFG}_{1}$ & 10.0 & 87.3 & 4.68 \\
& 1.0 & 88.2 & 7.00 \\
$\mathrm{AFG}_{2}$ & 10.0 & 83.1 & 2.00 \\
& 1.0 & 82.8 & 4.67 \\
$\mathrm{OTA}$ & 10.0 & 83.0 & 4.73 \\
& 2.0 & 92.8 & 4.51 \\
& 10.0 & 90.5 & 8.24 \\
\hline
\end{tabular}

${ }^{a}$ Mean recovery indicate the average of triplicates at each level

as meju is scarce. Therefore, greater attention is required for assessing and monitoring OTA contamination in mеju.

We also investigated the co-occurrence of AFs and OTA in the same mеju samples. The co-occurrence and co-contaminated levels were relatively lower than those in samples contaminated with only one of the toxins (Fig. 2). These results suggest that the same meju products are not likely to be co-infected with different fungi, which produce either AFs or OTA; even if the same products are co-infected, those fungi are not likely to produce toxins due to fungal competition.

The occurrence of AFs and OTA in meju was investigated on the basis of climate.

Samples from the first region (Yeongdong region in Gangwon and Gyeonggi provinces; average temperature, $11.7{ }^{\circ} \mathrm{C} /$ year; average precipitation, $1286.6 \mathrm{~mm} /$ year) showed higher mycotoxin contamination levels than those from the southern region (Jeollanam and Gyeongsangnam provinces; average temperature, $13{ }^{\circ} \mathrm{C} /$ year; average precipitation, $1346.9 \mathrm{~mm} /$ year $)(p<0.05)$ (Table 6). Also, samples from the second region (Chungcheongbuk, Chungcheongnam, Gyeongsangbuk, and Jeollabuk provinces; average temperature, $11.3{ }^{\circ} \mathrm{C} /$ year; average precipitation, $1263.4 \mathrm{~mm} /$ year) showed higher mycotoxin contamination levels than those from the third region (Jeollanam and Gyeongsangnam provinces) $(p<0.05)$ (Table 6). This result might be due to differences in the average winter temperatures in South Korea. Some parts of South Korea have very low temperatures in winter, which are unsuitable for the fermentation of meju. The average temperature in winter is below zero in the first and second regions $\left(-6.0\right.$ to $\left.0.7^{\circ} \mathrm{C}\right)$, while it is above zero in the southern region $\left(2.5\right.$ to $\left.3.9^{\circ} \mathrm{C}\right)$ [17]. As a result, in the southern region, meju can be exposed to different

Table 3 LOD and LOQ of AFs and OTA by HPLC analysis in meju

\begin{tabular}{llllll}
\hline Mycotoxin & LOD $^{\mathbf{a}}(\boldsymbol{\mu g} / \mathbf{k g})$ & $\mathbf{L O Q}^{\mathbf{b}} \mathbf{( \mu \mathbf { g } / \mathbf { k g } )}$ & Linear equation & $\mathbf{R}^{\mathbf{2} \mathbf{d}}$ & $\mathbf{R a n g e}(\boldsymbol{\mu g} / \mathbf{k g})$ \\
\hline $\mathrm{AFB}_{1}$ & 0.05 & 0.15 & $Y=2441.0 X+7.8015$ & 0.9974 & $0.01-10$ \\
$\mathrm{AFB}_{2}$ & 0.05 & 0.15 & $Y=2900.1 X-7.1994$ & 0.9974 & $0.01-10$ \\
$\mathrm{AFG}_{1}$ & 0.2 & 0.6 & $Y=1293.4 X+1.7867$ & 0.9988 & $0.01-10$ \\
$\mathrm{AFG}_{2}$ & 0.2 & 0.6 & $Y=1173.8 X+2.0294$ & 0.9976 & $0.01-10$ \\
$\mathrm{OTA}$ & 0.03 & 0.1 & $Y=3935.1 X+324.6316$ & 0.9996 & $0.005-10$ \\
\hline
\end{tabular}

a Limit of detection

b Limit of quantification

c $X=$ AFs or OTA concentration $(\mu \mathrm{g} / \mathrm{kg}), \mathrm{Y}=$ intensity

d Coefficient of determination

Table 4 LOD and LOQ of AFs and OTA by HPLC analysis in soybean paste

\begin{tabular}{llllll}
\hline Mycotoxin & LOD $(\boldsymbol{\mu g} / \mathbf{k g})^{\mathbf{a}}$ & LOQ $(\boldsymbol{\mu g} / \mathbf{k g})^{\mathbf{b}}$ & Linear equation $^{\mathbf{c}}$ & $\mathbf{R}^{\mathbf{2} \mathbf{}}$ & $\mathbf{R a n g e}(\boldsymbol{\mu g} / \mathbf{k g})$ \\
\hline $\mathrm{AFB}_{1}$ & 0.01 & 0.03 & $y=2.5259 x+0.4332$ & 0.9978 & $0.005-10$ \\
$\mathrm{AFB}_{2}$ & 0.01 & 0.03 & $y=0.6885 x+0.1409$ & 0.9981 & $0.005-10$ \\
$\mathrm{AFG}_{1}$ & 0.05 & 0.15 & $y=1.4595 x+0.2503$ & 0.9978 & $0.005-10$ \\
$\mathrm{AFG}_{2}$ & 0.05 & 0.15 & $y=1.0506 x-0.0995$ & 0.9926 & $0.005-10$ \\
$\mathrm{OTA}$ & 0.01 & 0.03 & $y=0.6885 x+0.1409$ & 0.9971 & $0.005-10$ \\
\hline
\end{tabular}

\footnotetext{
a Limit of detection

${ }^{b}$ Limit of quantification

c $X=$ AFs or OTA concentration $(\mu \mathrm{g} / \mathrm{kg}), \mathrm{Y}=$ intensity

${ }^{d}$ Coefficient of determination
} 
Table 5 Natural occurrence of AFs and OTA in meju

\begin{tabular}{|c|c|c|c|c|c|c|c|c|}
\hline \multirow[t]{2}{*}{ Mycotoxin } & \multirow{2}{*}{$\begin{array}{l}\text { Positive samples/total } \\
\text { samples (percentage) }\end{array}$} & \multirow[t]{2}{*}{ Mean $(\mu \mathrm{g} / \mathrm{kg})$} & \multirow[t]{2}{*}{ Range $(\mu \mathrm{g} / \mathrm{kg})$} & \multicolumn{5}{|c|}{ Number of positive samples in the range } \\
\hline & & & & ND & $\begin{array}{l}0.1-1.0 \\
(\mu \mathrm{g} / \mathrm{kg})\end{array}$ & $\begin{array}{l}1.1-10.0 \\
(\mu \mathrm{g} / \mathrm{kg})\end{array}$ & $\begin{array}{l}10.1-100.0 \\
(\mu \mathrm{g} / \mathrm{kg})\end{array}$ & $\begin{array}{l}100.1- \\
200.0(\mu \mathrm{g} \\
\mathrm{kg})\end{array}$ \\
\hline $\mathrm{AFB}_{1}$ & $9 / 100(9.0 \%)$ & $0.86 \pm 63.51$ & $0.6-21.4$ & 91 & 1 & 5 & 3 & 0 \\
\hline AFB2 & $3 / 100(3.0 \%)$ & $0.38 \pm 2.59$ & $1.4-19.9$ & 97 & 0 & 1 & 2 & 0 \\
\hline $\mathrm{AFG}_{1}$ & $5 / 100(5.0 \%)$ & $0.20 \pm 1.86$ & $0.1-18.6$ & 95 & 4 & 0 & 1 & 0 \\
\hline $\mathrm{AFG}_{2}$ & $1 / 100(1.0 \%)$ & $0.01 \pm 0.11$ & 1.1 & 99 & 0 & 1 & 0 & 0 \\
\hline AFs & $10 / 100(10 \%)$ & $1.45 \pm 6.60$ & $0.2-41.3$ & 90 & 2 & 5 & 3 & 0 \\
\hline OTA & $50 / 100(50.0 \%)$ & $10.31 \pm 33.49$ & $0.1-193.2$ & 50 & 27 & 12 & 5 & 6 \\
\hline
\end{tabular}

ND none detectable

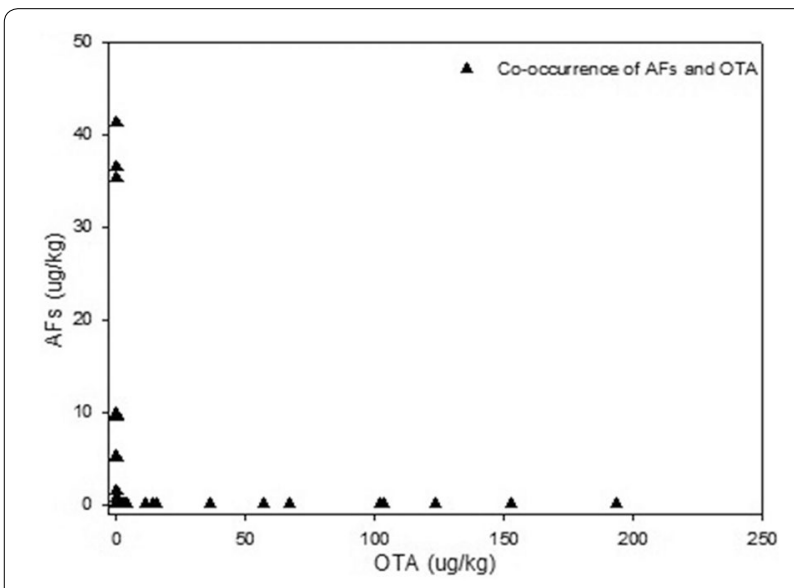

Fig. 2 Co-occurrence of AFs in OTA positive meju samples fungi in the outside air, causing competition among many different fungi and resulting in the inhibition of mycotoxin production [3, 27]. In contrast, in the first and second regions, meju is dried inside households. Thus, only a few specific fungi such as mycotoxin-producing fungi can contaminate meju. In this case, less competition between different fungi could increase the probability of mycotoxin contamination in meju. A previous study showed no AFs in samples from northern Korea [28]. Our data demonstrate that mycotoxin contamination is a function of climatic conditions to a certain extent.

\section{Monitoring the levels of AFs and OTA in soybean paste samples}

In total, 45 soybean paste samples were analyzed for AFs using HPLC. Eleven out of 45 samples (24.4\%) were

Table 6 Occurrence of AFs and OTA in meju from three areas

\begin{tabular}{|c|c|c|c|c|c|c|c|c|c|}
\hline \multicolumn{2}{|l|}{ Region } & \multicolumn{8}{|c|}{ Number of positive samples/total number of samples } \\
\hline & & \multicolumn{6}{|l|}{ Range } & \multicolumn{2}{|l|}{ Mean } \\
\hline & & $\begin{array}{l}\mathrm{AFB}_{1} \\
(\mu \mathrm{g} / \mathrm{kg})\end{array}$ & $\begin{array}{l}\mathrm{AFB}_{2} \\
(\mu \mathrm{g} / \mathrm{kg})\end{array}$ & $\begin{array}{l}A F G_{1} \\
(\mu g / k g)\end{array}$ & $\begin{array}{l}\mathrm{AFG}_{2} \\
(\mu \mathrm{g} / \mathrm{kg})\end{array}$ & $\begin{array}{l}\text { Total AFs } \\
(\mu \mathrm{g} / \mathrm{kg})\end{array}$ & $\begin{array}{l}\text { OTA } \\
(\mu g / k g)\end{array}$ & $\begin{array}{l}\text { Total AFs } \\
\text { (mean, } \\
\mu \mathrm{g} / \mathrm{kg} \text { ) }\end{array}$ & $\begin{array}{l}\text { Total OTA } \\
\text { (mean, } \mu \mathrm{g} / \\
\text { kg) }\end{array}$ \\
\hline \multirow[t]{3}{*}{ Area I } & Seoul & $1 / 3(0.6)$ & $0 / 3(<0.0)$ & $1 / 3(0.1)$ & $0 / 3(<0.0)$ & $0 / 3(<0.0)$ & $2 / 3(57-115.5)$ & $4 / 31(0.8)$ & $15 / 31(24.6)$ \\
\hline & Gyeonggi & $1 / 17(4.9)$ & $0 / 17(<0.0)$ & $1 / 17(0.2)$ & $0 / 17(<0.0)$ & $1 / 17(5.1)$ & $6 / 17(0.3-152.4)$ & & \\
\hline & Gangwon & $3 / 11(5.5-9.7)$ & $1 / 11(1.4)$ & $1 / 11(0.2)$ & $0 / 11(<0.0)$ & $3 / 11(5.7-9.8)$ & $7 / 11(0.1-193.2)$ & & \\
\hline \multirow[t]{4}{*}{ Area II } & $\begin{array}{l}\text { Chungcheong- } \\
\text { buk }\end{array}$ & $0 / 7(<0.0)$ & $0 / 7(<0.0)$ & $0 / 7(<0.0)$ & $0 / 7(<0.0)$ & $0 / 7(<0.0)$ & 3/7 (0.7-3.0) & $4 / 35(3.2)$ & 18/35 (6.8) \\
\hline & $\begin{array}{l}\text { Chungcheong- } \\
\text { nam }\end{array}$ & 1/7 (19.6) & 1/7 (16.9) & $0 / 7(<0.0)$ & $0 / 7(<0.0)$ & $1 / 7(36.5)$ & $5 / 7(0.1-67.0)$ & & \\
\hline & Gyungsangbuk & $1 / 12(21.4)$ & 1/12 (19.9) & $0 / 12(<0.0)$ & $0 / 12(<0.0)$ & $1 / 12(41.3)$ & $6 / 12(0.6-36.0)$ & & \\
\hline & Jeollabuk & 1/9 (15.6) & $0 / 9(<0.0)$ & 2/9 (0.2-18.6) & 1/9 (1.1) & 2/9 (0.2-35.3) & 4/9 (0.2-102.0) & & \\
\hline \multirow[t]{2}{*}{ Area III } & Jeollanam & $1 / 17(4.5)$ & $0 / 17(<0.0)$ & $1 / 17(0.6)$ & $0 / 17(<0.0)$ & $1 / 17(5.2)$ & $12 / 17(0.1-3.7)$ & 2/31 (0.2) & 18/34 (0.7) \\
\hline & $\begin{array}{l}\text { Gyungsang- } \\
\text { nam }\end{array}$ & $1 / 17(1.5)$ & $0 / 17(<0.0)$ & $0 / 17(<0.0)$ & $0 / 17(<0.0)$ & $1 / 17(1.5)$ & 6/17 (0.1-11.1) & & \\
\hline
\end{tabular}


Table 7 Natural occurrence of AFs and OTA in soybean paste

\begin{tabular}{|c|c|c|c|c|c|c|c|c|}
\hline \multirow[t]{2}{*}{ Mycotoxin } & \multirow{2}{*}{$\begin{array}{l}\text { Positive samples/total } \\
\text { samples (percentage) }\end{array}$} & \multirow[t]{2}{*}{ Mean $(\mu \mathrm{g} / \mathrm{kg})$} & \multirow[t]{2}{*}{ Range $(\mu \mathrm{g} / \mathrm{kg})$} & \multicolumn{5}{|c|}{ Number of positive samples in the range } \\
\hline & & & & ND & $\begin{array}{l}0.1-1.0 \\
(\mu \mathrm{g} / \mathrm{kg})\end{array}$ & $\begin{array}{l}1.1-10.0 \\
(\mu \mathrm{g} / \mathrm{kg})\end{array}$ & $\begin{array}{l}10.1-20.0 \\
(\mu \mathrm{g} / \mathrm{kg})\end{array}$ & $\begin{array}{l}20.1-50.0 \\
(\mu \mathrm{g} / \mathrm{kg})\end{array}$ \\
\hline $\mathrm{AFB}_{1}$ & $4 / 45(8.9 \%)$ & $0.59 \pm 2.52$ & $1.06-15.25$ & 41 & 0 & 3 & 1 & 0 \\
\hline $\mathrm{AFB}_{2}$ & $5 / 45(11.1 \%)$ & $0.34 \pm 1.29$ & $0.92-7.80$ & 40 & 1 & 4 & 0 & 0 \\
\hline $\mathrm{AFG}_{1}$ & $1 / 45(2.2 \%)$ & $0.12 \pm 0.78$ & 5.24 & 44 & 0 & 1 & 0 & 0 \\
\hline $\mathrm{AFG}_{2}$ & $2 / 45(4.4 \%)$ & $0.05 \pm 0.25$ & $0.88-1.44$ & 43 & 0 & 2 & 0 & 0 \\
\hline AFs & $11 / 45(24.4 \%)$ & $1.09 \pm 2.93$ & $0.88-16.17$ & 34 & 1 & 9 & 1 & 0 \\
\hline OTA & $22 / 45$ (48.9\%) & $4.43 \pm 7.25$ & $0.88-26.29$ & 23 & 1 & 14 & 3 & 4 \\
\hline
\end{tabular}

$N D$ none detectable

Table 8 Occurrence of AFs and OTA of soybean paste from three areas

\begin{tabular}{|c|c|c|c|c|c|c|c|c|c|}
\hline \multirow[t]{3}{*}{ Region } & & \multicolumn{8}{|c|}{ Number of positive samples/total number of samples } \\
\hline & & \multicolumn{6}{|l|}{ Range } & \multicolumn{2}{|l|}{ Mean } \\
\hline & & $A F B_{1}(\mu \mathrm{g} / \mathrm{kg})$ & $\mathrm{AFB}_{2}(\mu \mathrm{g} / \mathrm{kg})$ & $\begin{array}{l}\mathrm{AFG}_{1}(\mu \mathrm{g} / \\
\mathrm{kg})\end{array}$ & $\begin{array}{l}\mathrm{AFG}_{2}(\mu \mathrm{g} / \\
\mathrm{kg})\end{array}$ & $\begin{array}{l}\text { Total AFs }(\mu \mathrm{g} / \\
\mathrm{kg})\end{array}$ & ОТА $(\mu \mathrm{g} / \mathrm{kg})$ & $\begin{array}{l}\text { Total AFs } \\
\text { (mean, } \mu \mathrm{g} / \\
\mathrm{kg} \text { ) }\end{array}$ & $\begin{array}{l}\text { Total OTA } \\
\text { (mean, } \mu \mathrm{g} / \\
\mathrm{kg} \text { ) }\end{array}$ \\
\hline \multirow[t]{3}{*}{ Area I } & Seoul & $2 / 5(7.3-15.3)$ & $3 / 5(0.9-7.8)$ & $0 / 5(<0.0)$ & $0 / 5(<0.0)$ & $4 / 5(1.1-16.2)$ & $3 / 5(6.9-22.9)$ & $7 / 15(2.58)$ & $9 / 15(4.04)$ \\
\hline & Gyeonggi & $1 / 8(1.1)$ & $2 / 8(1.8-3.4)$ & $0 / 8(<0.0)$ & $0 / 8(<0.0)$ & $3 / 8(1.1-3.4)$ & $5 / 8(1.6-6.2)$ & & \\
\hline & Gangwon & $0 / 2(<0.0)$ & $0 / 2(<0.0)$ & $0 / 2(<0.0)$ & $0 / 2(<0.0)$ & $0 / 2(<0.0)$ & $1 / 2(0.88)$ & & \\
\hline \multirow[t]{4}{*}{ Area II } & $\begin{array}{l}\text { Chungcheong- } \\
\text { buk }\end{array}$ & $0 / 3(<0.0)$ & $0 / 3(<0.0)$ & $0 / 3(<0.0)$ & $0 / 3(<0.0)$ & $0 / 3(<0.0)$ & $2 / 3(1.6-1.7)$ & $1 / 15(0.8)$ & 13/15 (9.3) \\
\hline & $\begin{array}{l}\text { Chungcheong- } \\
\text { nam }\end{array}$ & $0 / 4(<0.0)$ & $0 / 4(<0.0)$ & $0 / 4(<0.0)$ & $0 / 4(<0.0)$ & $0 / 4(<0.0)$ & $4 / 4(2.5-24.1)$ & & \\
\hline & Gyungsangbuk & $0 / 4(<0.0)$ & $0 / 4(<0.0)$ & $0 / 4(<0.0)$ & $1 / 4(1.44)$ & $1 / 4(<1.44)$ & $3 / 4(2.8-26.3)$ & & \\
\hline & Jeollabuk & $0 / 4(<0.0)$ & $0 / 4(<0.0)$ & $0 / 4(<0.0)$ & $0 / 4(<0.0)$ & $0 / 4(<0.0)$ & 4/4 (3.2-14.6) & & \\
\hline \multirow[t]{2}{*}{ Area III } & Jeollanam & $1 / 8(2.8)$ & $0 / 8(<0.0)$ & $1 / 8(5.2)$ & $0 / 8(<0.0)$ & $2 / 8(2.8-5.2)$ & $0 / 8(<0.0)$ & $3 / 15(0.59)$ & $0 / 15(0.0)$ \\
\hline & Gyungsangnam & $0 / 7(<0.0)$ & $0 / 7(<0.0)$ & $0 / 7(<0.0)$ & $1 / 7(0.9)$ & $1 / 7(0.9)$ & $0 / 8(<0.0)$ & & \\
\hline
\end{tabular}

contaminated with total AFs at levels of 0.88-16.17 $\mu \mathrm{g}$ / $\mathrm{kg}$ (Table 7). Furthermore, four samples (8.9\%) were contaminated with $\mathrm{AFB}_{1}$ at $1.06-15.25 \mu \mathrm{g} / \mathrm{kg}$. The mean concentrations of $\mathrm{AFB}_{1}$ and total AFs were $0.59 \mu \mathrm{g} / \mathrm{kg}$ and $1.09 \mu \mathrm{g} / \mathrm{kg}$, respectively (Table 7). The levels of $\mathrm{AFB}_{1}$ and total AF in one sample analyzed exceeded the regulatory limits for $\mathrm{AFB}_{1}(10 \mu \mathrm{g} / \mathrm{kg})$ and total $\mathrm{AF}(15 \mu \mathrm{g} / \mathrm{kg})$ set by the KFDA. In a previous study, 5 out of 11 samples analyzed (45.5\%) were within the permissible levels, ranging $0.04-2.46 \mu \mathrm{g} / \mathrm{kg}$ [21]. These data indicate that continuous management of AF risk is necessary during soybean paste manufacturing. In addition, 45 soybean paste samples were analyzed for OTA levels using HPLC. Twentytwo samples $(48.9 \%)$ were contaminated with OTA at $0.88-26.29 \mu \mathrm{g} / \mathrm{kg}$ (Table 7); the mean concentration was $4.43 \mu \mathrm{g} / \mathrm{kg}$. These results are similar to the average contamination $(7.1 \mu \mathrm{g} / \mathrm{kg})$ of soybean paste described by park et al. [24]. The levels of OTA in five soybean paste samples analyzed (11.1\%) exceeded the permissible limits for OTA in meju set by the KFDA $(20 \mu \mathrm{g} / \mathrm{kg})$ when the limit for OTA in meju was used for comparison as the legal limits for OTA in soybean paste are not yet established in South Korea. Thus, the establishment of legal limits for OTA in soybean paste and risk management are required for the soybean paste industry.

In addition, the occurrence of AFs and OTA in soybean paste was investigated on the basis of local climate. Unlike the severe contamination of $m e j u$, the contamination level was low in soybean paste (Table 8). There were no regional differences in the levels of AFs and OTA in the samples.

Reduction in the levels of AFs and OTA in meju samples contaminated with high amounts of the toxins during soy sauce and soybean paste production

Soy sauce and soybean paste are produced after the ripening of fermented meju (Fig. 3). To investigate the levels of AFs and OTA in soy sauce and soybean paste after the 

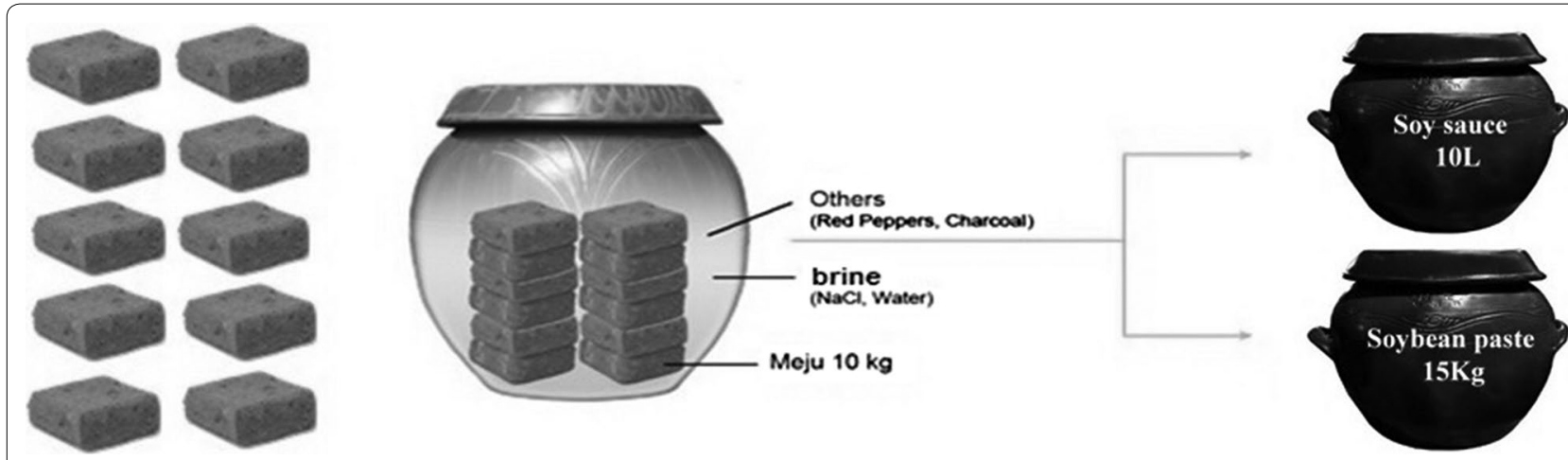

Fig. 3 General scheme for the production of soy sauce and soybean paste from meju

Table 9 Levels of AFs and OTA in meju, soy sauce, and soybean paste collected from the same household

\begin{tabular}{llll}
\hline Mycotoxin & $\boldsymbol{M} \boldsymbol{j} \boldsymbol{j} \boldsymbol{( \boldsymbol { \mu g } / \mathbf { k g } )}$ & Soy sauce $(\boldsymbol{\mu g} / \mathbf{k g})$ & $\begin{array}{l}\text { Soybean paste } \\
(\boldsymbol{\mu} \mathbf{g} / \mathbf{k g})\end{array}$ \\
\hline $\mathrm{AFB}_{1}$ & $620.0 \pm 6.49$ & $0.49 \pm 0.02$ & $13.29 \pm 0.70$ \\
$\mathrm{AFB}_{2}$ & $9.7 \pm 1.99$ & $0.48 \pm 0.01$ & $13.20 \pm 0.60$ \\
$\mathrm{AFG}_{1}$ & $1.2 \pm 0.32$ & $0.49 \pm 0.01$ & $13.30 \pm 0.61$ \\
$\mathrm{AFG}_{2}$ & 0 & $0.48 \pm 0.02$ & $13.25 \pm 0.50$ \\
$\mathrm{OTA}$ & $1738.31 \pm 25.69$ & $7.53 \pm 0.32$ & $190.47 \pm 4.11$ \\
\hline
\end{tabular}

ripening of $m e j u$, we collected $m e j u$ samples, which were contaminated with high amounts of AFs $(620.0 \mu \mathrm{g} / \mathrm{kg})$ and OTA $(1738.3 \mu \mathrm{g} / \mathrm{kg})$, soy sauce samples, and soybean paste samples in the same household in 2016, which were prepared from the meju. Both soy sauce and soybean paste were collected 8 months after meju sampling. In this study, we assumed that soy sauce and soybean paste from meju were produced as shown in Fig. 3. Briefly, $10 \mathrm{~kg}$ of $m e j u$ and $30 \mathrm{~L}$ of brine (about $20 \% \mathrm{NaCl}$ ) were used for the production of soy sauce and soybean paste. After the ripening of meju in the brine, the mashed meju was filtered, and the paste was separated from the liquid. Finally, $25 \mathrm{~L}$ of liquid (soy sauce) and $15 \mathrm{~kg}$ of soybean paste were obtained without any loss [29]. When soybean paste and soy sauce are made in the traditional way, fermented meju is matured for several months in brine. AFs and OTA production would not occur during the ripening of fermented meju because the fungus cannot grow and produce AFs under $>14 \%$ salt concentration (22\%). Therefore, mycotoxins levels are expected to decline or stay at a certain value [30]. Table 9 shows that the levels of $\mathrm{AFB}_{1}$ and OTA were $0.5 \mu \mathrm{g} / \mathrm{kg}$ and $7.5 \mu \mathrm{g} / \mathrm{kg}$ in soy sauce and $11.9 \mu \mathrm{g} / \mathrm{kg}$ and $190.4 \mu \mathrm{g} / \mathrm{kg}$ in soybean paste, respectively. It was presumed that $12.5 \mu \mathrm{g}$ of $\mathrm{AFB}_{1}$ and $1882.5 \mu \mathrm{g}$ of OTA were present in $25 \mathrm{~L}$ soy sauce and that $178.5 \mu \mathrm{g}$ of $\mathrm{AFB}_{1}$ and $2790 \mu \mathrm{g}$ OTA were present in $15 \mathrm{~kg}$ soybean paste (Fig. 4). These results suggest that considerable amounts of $\mathrm{AFB}_{1}$ (97\%) and OTA (73\%) were degraded during the production of soy sauce and soybean paste from meju. $\mathrm{AFB}_{1}$ and OTA were almost completely degraded. There are various reasons why the mycotoxins were degraded. Various microorganisms are known to inhibit mycotoxin production. Cho and co-workers reported the degradation of OTA using A. tubingensis isolated from meju [31]. In their study, OTA degradation was about $95 \%$ after 14 days. Kim and collaborators studied the effect of mixed culture conditions in a liquid medium and soybean mash and reported that $A$. niger reduced AF formation, but other microorganisms did not interfere with AF production [10]. Petchkongkaew and colleagues reported the detoxification of AFs and OTA by using Bacillus licheniformis isolated from fresh Thuanao (a fermented soybean product) collected from north Thailand $\left(74 \%\right.$ decrease in $\mathrm{AFB}_{1}$ and $92.5 \%$ decrease in OTA) [32]. However, in our study we cannot rule out the possibility that mycotoxins in the final products might be adsorbed onto charcoal during the soybean paste and soy sauce preparation even though charcoal addition to home-made soy sauce had negligible effects on $\mathrm{AFB}_{1}$ degradation (about $5 \% \mathrm{AFB}_{1}$ degradation) in the soy sauce in one study described by Park et al. [27].

Both AF and OTA contamination in meju can cause public health hazards even at low levels. Our data showed that OTA contamination in meju was more frequent than AF contamination. Therefore, although greater management of OTA is necessary than of AFs in meju, regular monitoring and control of both mycotoxins in meju and soybean paste are crucial for the fermented food industry in South Korea. 


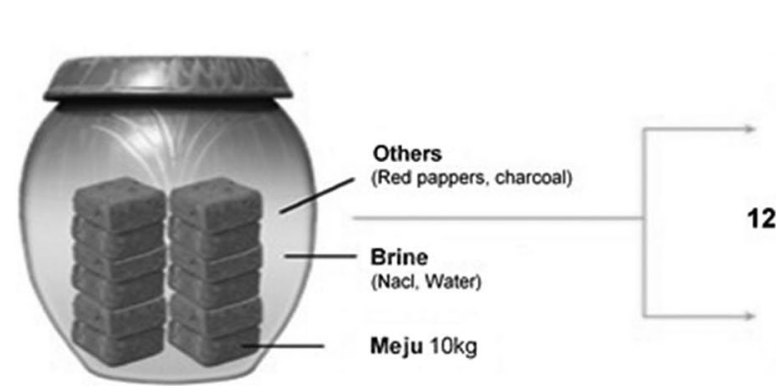

AFB1 in total amount of meju: Ca. 6,200 $\mu \mathrm{g} / 10 \mathrm{~kg}$ meju

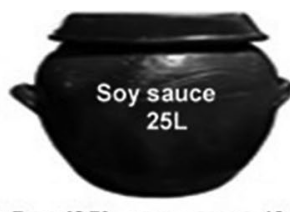

$12.5 \mu \mathrm{g} / 25 \mathrm{~L}$ soy sauce $(0.20 \%)$

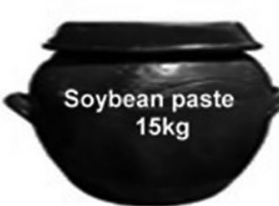

$178.5 \mu \mathrm{g} / 15 \mathrm{~kg}$ soybean paste $(2.88 \%)$
Degradation: ca. $97 \%$

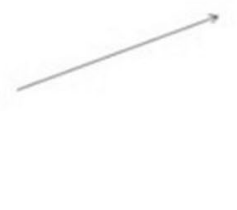

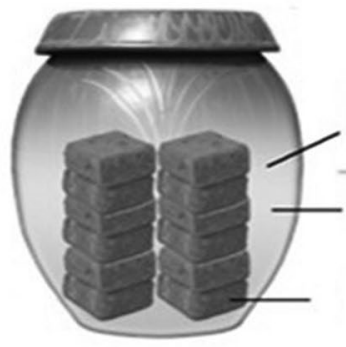

OTA in total amount of meju: Ca. $17,383 \mu \mathrm{g} / 10 \mathrm{~kg}$ meju

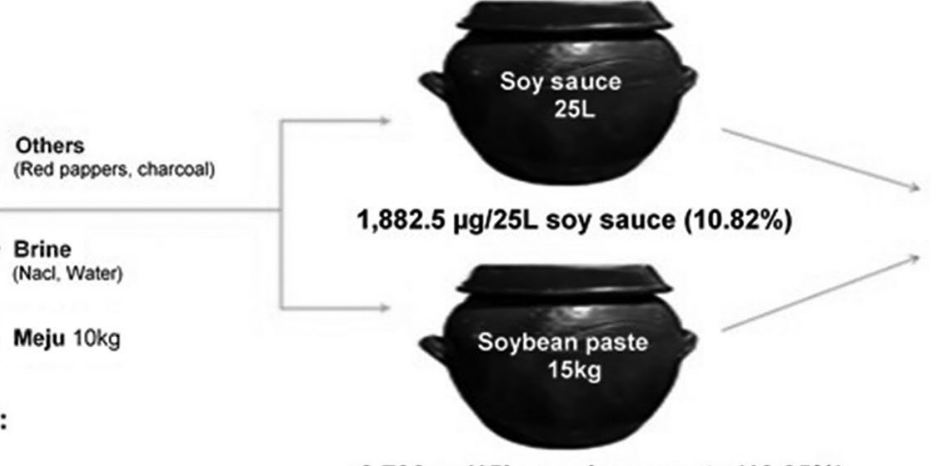

$\mathbf{2 , 7 9 0} \boldsymbol{\mu g} / \mathbf{1 5} \mathrm{kg}$ soybean paste (16.05\%)

Fig. 4 Putative fate of $\mathrm{AFB}_{1}$ and OTA during the production of soy sauce and soybean paste from meju assuming that all meju samples contained the same levels of toxins

\section{Abbreviations}

AFs: aflatoxins; OTA: ochtatoxin $A_{A}$ : $A F B_{1}$ : aflatoxin $B_{1} ; A_{F} B_{2}$ : aflatoxin $B_{2} ; A_{F}$ : aflatoxin $\mathrm{G}_{1} ; \mathrm{AFG}_{2}$ : aflatoxin $\mathrm{G}_{2} ;$ A.: Aspergillus; IARC: International Agency for Research on Cancer; ELISA: enzyme-linked immunosorbent assay; TLC: thinlayer chromatography; HPLC: high-performance liquid chromatography; IAC: immunoaffinity column; ACN: acetonitrile; $\mathrm{MeOH}$ : methanol; HAC: acetic acid; TFA: trifluoroacetic acid; PBS: phosphate buffered saline; NaCl: sodium chloride; LOD: limit of detection; LOQ: limit of quantification; S/N: signal-to-noise ratio; AOAC: Association of Official Analytical Chemists; KFDA: Korea Food and Drug Administration; RSD: relative standard deviation.

\section{Acknowledgements}

Not applicable.

\section{Authors' contributions}

SEJ, SHC, and SYH conceived and designed the experiments. SEJ performed the experiments. SEJ, SHC, and SYH analyzed the data. SEJ and SYH wrote the manuscript. All authors read and approved the final manuscript.

\section{Funding}

This work was funded by Korea Research Foundation in South Korea. We authors thank for the support.

\section{Availability of data and materials}

Not applicable.

\section{Competing interests}

The authors declare that they have no competing interests.
Received: 18 July 2019 Accepted: 25 October 2019

Published online: 06 November 2019

References

1. Kim DH, Lee KH, Yook HS, Kim JH, Shin MG, Byun MW (2000) Quality characteristics of gamma irradiated-grain shape improved meju. Korean J Food Sci Technol 32:640-645

2. Lee KH, Kim ND, Yoo JY (1997) Survey on the manufacturing process of traditional meju for and of kanjang (Korean soy sauce). J Korean Soc Food Sci Nutr 26:390-396

3. Kim JS, Kim JG, Kim WJ (2004) Changes in isoflavone and oligosaccharides of soybeans during germination. Korean J Food Sci Technol 36:294-298

4. Abdin M, Ahmad MM, Javed S (2010) Advances in molecular detection of Aspergillus: an update. Arch Microbiol 192:409-425

5. Reddy K, Salleh B, Saad B, Abbas H, Abel C, Shier W (2010) An overview of mycotoxin contamination in foods and its implications for human health. J Toxicol Toxin Rev 29:3-26

6. IARC (2002) Some traditional herbal medicines, some mycotoxins, naphthalene and styrene. IARC Monogr Eval Carcinog 82:1-556

7. Abrunhosa L, Venâncio A (2007) Isolation and purification of an enzyme hydrolyzing ochratoxin A from Aspergillus niger. Biotechnol Lett 29:1909-1914

8. Wang Y, Wang L, Liu F, Wang Q, Selvaraj J, Xing F et al (2016) Ochratoxin A producing fungi, biosynthetic pathway and regulatory mechanisms. Toxicol Toxin Rev 8:83 
9. Lee KR, Yang SM, Cho SM, Kim M, Hong S-Y, Chung SH (2017) Aflatoxin B1 detoxification by Aspergillus oryzae from meju, a traditional Korean fermented soybean starter. J Biol Biotechnol 27:57-66

10. Kim EJ, Chung Y, Kwon SP (1976) Effect of various fungi on the aflatoxin productivity in the culture of Aspergillus flavus. J Prev Med Public Health 9:77-86

11. Kim Y-H, Hwangbo J-S, Lee S-R (1977) Detection of aflatoxins in some Korean foodstuffs. Korean J Food Sci Technol 9:73-80

12. Park K-Y, Lee E-S, Moon S-H, Cheigh H-S (1989) Effects of browning products and charcoal on the degradation of aflatoxin B, in Korean soy sauce (kanjang) and its model system. Bull Environ Contam Toxicol 21:419-424

13. Scott P, Lawrence J, Van Walbeek W (1970) Detection of mycotoxins by thin-layer chromatography: application to screening of fungal extracts. Appl Microbiol 20:839-842

14. Leitner A, Zöllner P, Paolillo A, Stroka J, Papadopoulou-Bouraoui A, Jaborek $S$ et al (2002) Comparison of methods for the determination of ochratoxin A in wine. Anal Chim Acta 453:33-41

15. Dallsta C, Galaverna G, Dossena A, Marchelli R (2004) Reversed-phase liquid chromatographic method for the determination of ochratoxin A in wine. J Chromatogr A 1024:275-279

16. Lutfullah G, Hussain A (2012) Studies on contamination level of aflatoxins in some cereals and beans of Pakistan. Food Control 23:32-36

17. Park C-Y, Choi Y-E, Moon J-Y, Yun W-T (2009) Classification of climate zones in South Korea considering both air temperature and rainfall. J Geo Soc Korea 44:1-16

18. Kim E, Shon D, Yoo J, Ryu D, Lee C, Kim Y (2001) Natural occurrence of aflatoxins in Korean meju. Food Addit Contam 18:151-156

19. Sripathomswat N, Thasnakorn P (1981) Survey of aflatoxin-producing fungi in certain fermented foods and beverages in Thailand. Mycopathologia 73:83-88

20. Wei R, Chang SC, Lee S (1980) High pressure liquid chromatographic determination of aflatoxins in soy sauce and fermented soybean paste. J Assoc Off Anal Chem 63:1269-1274

21. Park M-J, Yoo M-H, Hong H-G, Joe T-s, Lee I-s, Park J-H et al (2008) A survey of the presence of aflatoxins in food. J. Food Hyg Saf 23:108-112

22. Blesa J, Soriano J, Moltó J, Mañes J (2004) Absence ochratoxin A in soy sauce. Int J Food Microbiol 97:221-225
23. Brera C, Grossi S, De Santis B, Miraglia M (2003) Automated HPLC method for the determination of ochratoxin A in wine samples. J Liq Chromatogr Related Technol 26:119-133

24. Park S-K, Kwon K-S, Kim M-H, Jeong S-Y, Jang G-H, Nam T-H et al (2004) Survey of ochratoxin A in cereal-based Korean traditional foods by HPLC. Korean J Food Sci Technol 36:158-161

25. Horwitz W (1975) Official methods of analysis, pp edn. Association of Official Analytical Chemists, Washington, DC

26. Chang Y, Beng C, Ponnapalam J (1966) Mouldy soybeansas potential source of aflatoxin contamination. Far East Med J 2:298-300

27. Park K-Y, Lee K-B, Bullerman LB (1988) Aflatoxin production by Aspergillus parasiticus and its stability during the manufacture of Korean soy paste (doenjang) and soy sauce (kanjang) by traditional method. J Food Prot 51:938-944

28. Kim Y-K, Roh J-K (1985) Detection of aflatoxins in soybean food by HPLC. Korean J Food Sci Technol 17:295-303

29. Park K-Y, Hwang K-M, Jung K-O, Lee K-B (2002) Studies on the standardization of doenjang (Korean soybean paste): 1. Standardization of manufacturing method of doenjang by literatures. J Korean Soc Food Sci Nutr 31:343-350

30. Nagarajan V, Bhat R, Tulpule P (1973) Aflatoxin production in some varieties of soybeans (Glycine max L.). Experientia 29:1302-1303

31. Cho SM, Jeong SE, Lee KR, Sudhani HP, Kim M, Hong S-Y et al (2016) Biodegradation of ochratoxin a by Aspergillus tubingensis isolated from meju. J Microbiol Biotechnol 26:1687-1695

32. Petchkongkaew A, Taillandier P, Gasaluck P, Lebrihi A (2008) Isolation of Bacillus spp. from Thai fermented soybean (Thua-nao): screening for aflatoxin B1 and ochratoxin A detoxification. J Appl Microbiol 104:1495-1502

\section{Publisher's Note}

Springer Nature remains neutral with regard to jurisdictional claims in published maps and institutional affiliations.

\section{Submit your manuscript to a SpringerOpen ${ }^{\circ}$ journal and benefit from:}

- Convenient online submission

- Rigorous peer review

- Open access: articles freely available online

- High visibility within the field

- Retaining the copyright to your article

Submit your next manuscript at springeropen.com 